\section{医療施設の設計者等選定マニュ アルの基本構成の作成}

\title{
BASIC CONSTRUCTION OF MANUAL FOR SELECTING ARCHITECTS OF HEALTH CARE FACILITY DESIGN
}

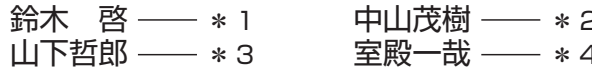

恒川真一

キーワード :

医療施設, 設計者選定, 発注者, 設計プロセス, プログラミング, 与条件

\section{Keywords:}

Health care facility, Selecting Architects, Ordering party, Design process, Programing, Design Briefing

\section{Hiromu SUZUKI \\ Shigeki NAKAYAMA \\ Tetsurou YAMASHITA — $* 3$ Kazuya MURODONO $-* 4$ \\ Shinichi TSUNEKAWA — $* 5$}

The authors developed a basic construction of manual that intended to guide ordering party of health care facility to the appropriate method for selecting architects. Before developing, the authors interviewed with design offices and general contractors about the problem of selecting architects that results from ordering party's arrangement. As a result, it became that there are four causes of the thise problems which are "content of Design Briefing","object of selection", "format of selection", "contract".

Firstly,this manual have ordering party realize the progress of own project, and select the category of industry of design outsourcing. Next this have ordering party select the way of selecting architects, and then give account it circumstantially.

\section{1 . はじめに}

公共建築の設計者選定において、プロポーザル方式の採用が一般 的となっている。この方式は、設計料入札を不適切とする動きの中、 特命方式より透明性・公正性を有し、設計競技方式よりも発注者と 応募者の負担が軽く効率的であることが利点として挙げられている 1)。公共建築協会が定めたマニュアル2) は、この方式を応募者の実 績や業務実施体制、課題に対する提案などで設計者を選定するもの としており、特に提案については「文章で表現し、図面表現を避ける」 としている。

一方、医療福祉建築のプロポーザル方式については「大手事務所 指名に偏っている、歴史の浅い事務所や規模の大きくない事務所に は不利である、提案における図面表現の禁止は不自由である、選考 の過程の不透明なケースがある」などが問題とされ、これを改善す るためのガイドライン ${ }^{3)}$ が発表されている。特に「図面的表現の禁 止は、部門間ならびに室間の機能的関連性の理解の提示が不可欠で ある医療・福祉施設にとってかなり不都合な制約となっている」とし、 総合的な図面提案を求めるべきとしている。

これに対し、筆者らは病院建築のプロポーザル方式の現状に関す る調査 ${ }^{4)}$ を行い、「透明性や公平性、効率性に対する発注者の理解が 薄いこと」、「募集段階で提示されている与条件等の情報内容が事例 により様々であり、これにプロポーザル方式が対応しきれていない こと」などを問題として指摘し、さらに「発注者の状況に対応でき る設計者選定方式のバリエーションと、その実施までの手引きの作 成が必要である」と提案した。

そこで、設計者選定場面での発注者の準備不足や認識不足に起因 する問題点と、その具体的な要因となる状況を現状調查により明ら
かにし、これを回避するための「設計者選定方法の選択と実施方針」 を示すマニュアルの基本構成を作成した。これは、発注者を導くた めのマニュアルをWeb 上で展開することを想定したものの第 1 段階 として作成したものである。この調查結果とマニュアルの概要を報 告する。

\section{2. 現状調査}

\section{（1）調査の目的}

近年実施された医療施設の設計者選定において、発注者の準備不 足に起因する問題と、具体的なその要因を把握し、マニュアルで示 すべき内容を検討することを目的とした。

\section{（2）調査の方法}

対象：建設会社設計部 5 社，設計事務所 5 社（日本医療福祉建築協 会法人会員より任意に選出)

方法 : ヒアリング

内容 : 発注者側の準備状況などが原因で、提案の応募時や特定後の 設計に問題や困惑のあった病院建築事例に関する「問題エピ ソード」について

(3) 分析

\section{問題の要因（発注側）を抽出}

ヒアリングで収集した各エピソードを、「(1)与条件内容」、「(2)選定 対象」、「(3選定の進め方」「(4)契約」の4つの問題の要因で分類した。 この分類のもと、類似内容などを整理したエピソードの一覧を表に 示寸 (表 1 )。

(1)は、求める提案に対し示される与条件項目が不足していたり、 示されていたとしても具体的な内容が未確定であったりという、不

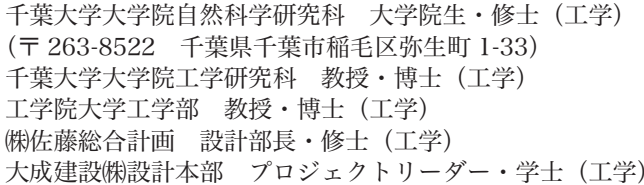

Graduate Student, Chiba Univ., M. Eng.

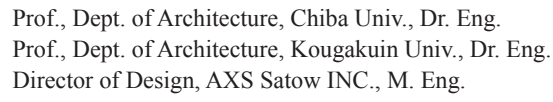


表 1 収集エピソード一覧

\begin{tabular}{|c|c|c|}
\hline 奋 & $\begin{array}{l}\text { 番 } \\
\text { 号 }\end{array}$ & 問題エピソード \\
\hline & II & 容 \\
\hline & 1 & $\begin{array}{l}\text { 選定時には非常にタイトな建替え案を提案したが、特定後に要項の敷地境界 } \\
\text { 線が不正確であることが判明し、計画案を見直す必要が生じた。 } \\
\end{array}$ \\
\hline & 2 & $\begin{array}{l}\text { 特定後、敷地の土壤に污染物が含まれていることが判明し、工程調査などの } \\
\text { 業務を追加でせざをえっった }\end{array}$ \\
\hline & 3 & $\begin{array}{l}\text { 選定時には公表されていなかった既存部分等の諸条件が特定後に示され、 } \\
\text { 当初設定工事費内での計画案の履行が困難となった } \\
\end{array}$ \\
\hline & 4 & $\begin{array}{l}\text { 実施設計からの業務であったが、示された基本設計の完成度が低く（行政と } \\
\text { の調整や集団規定との整合、スタッフへのヒアリング等）、実施設計の設計料 } \\
\text { と期間で基本設計からや直すこととなった。 }\end{array}$ \\
\hline & 5 & $\begin{array}{l}\text { 特定後、要項で示されていた諸条件の根拠である基本設計が提示されたが、 } \\
\text { 規模やコストの整合が取れてなかったために全体規模の設定からやり直すこ } \\
\text { ととなっ。 }\end{array}$ \\
\hline & 6 & 設計途中で敷地買収が不可能となり、計画が頓挫した。 \\
\hline & 7 & $\begin{array}{l}\text { 敷地形状が未確定のままでの提案を求められ、特定後、ほとんど } 1 \text { から計画 } \\
\text { をやり直すこととなった。 }\end{array}$ \\
\hline & 8 & $\begin{array}{l}\text { 既存建物や敷地状況の図が示されずに提案を求められたため、敷地を想定 } \\
\text { し取得手段も含めた検討を行う必要があり、各社が異なるる数字での提案と } \\
\text { なった。そのため、再度条件を揃えての提案を求められた。 } \\
\end{array}$ \\
\hline & 9 & $\begin{array}{l}\text { 特定後に敷地が拡張され、建屋も拡大し、提案時の予算をオーバーすること } \\
\text { となった。 }\end{array}$ \\
\hline & 10 & $\begin{array}{l}\text { 事業内容が曖昧なままで提案を求められ提出したが、その後要項を配布され } \\
\text { た上で再提案を求められ、ゼロから計画しなおすこととなった。 } \\
\end{array}$ \\
\hline & 11 & $\begin{array}{l}\text { 建替えの工事費が予算に合わないこと、運営悪化などから、事業が中止と } \\
\text { なった }\end{array}$ \\
\hline & 12 & $\begin{array}{l}\text { 病床数が未定段階での選定により特定を受けたが、基本設計終了直前に決 } \\
\text { 定したため、提案時の設計案を急遽变更せざるを得なかった。 }\end{array}$ \\
\hline & 13 & $\begin{array}{l}\text { 最適病床数の検討も含めての提案を求められたが、各社の提案病床数が異 } \\
\text { なり審査がでぎ、結局想定大值での再提案を求められた。 }\end{array}$ \\
\hline & 対空 & \\
\hline & 14 & $\begin{array}{l}\text { 設計事務所と施工会社とが混在した指名プロポーザルであったため、発注者が } \\
\text { 提案に何を求めているかの判に困難があった。 } \\
\end{array}$ \\
\hline & 15 & $\begin{array}{l}\text { 建設会社と設計事務所の混合プロポーザルであり、工事費の提案も求められ } \\
\text { たが、吿者の提示する金額は意味合いが異なるため、公平な競技となりにく } \\
\text { い。設計事務所が受注した場合に、示され定価格内での提案であっても } \\
\text { 施工の段階で無理が発覚し、入札が難航するケースもる。 } \\
\end{array}$ \\
\hline & 16 & $\begin{array}{l}\text { 設計事務所と建設会社の混合型であり、各 } 1 \text { 社ずつ選出されたが、選定後の } \\
\text { 依頼業務内容が不明瞭であったため、役割分担が不明確なまま進み、無太䭾 } \\
\text { な作業や、意見の食い違いなどからやり直しの作業が多く発生した。 }\end{array}$ \\
\hline & 17 & 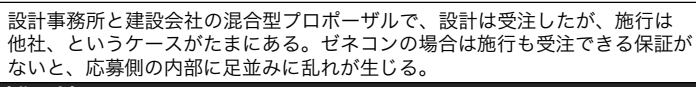 \\
\hline & 定方汪 & ( \\
\hline & 18 & $\begin{array}{l}\text { 特定後（優先交渉権）に、極めて安い建設単価で追加条件を要求され、根拠 } \\
\text { と共に難しいと回答したら定外とった。 }\end{array}$ \\
\hline & 19 & $\begin{array}{l}\text { 募集要項では簡素な要件のみの提示であったが、基本構想書を入手できて } \\
\text { いる所といないと所で差が生した。 } \\
\end{array}$ \\
\hline & 20 & $\begin{array}{l}\text { 提案の要件を口頭で説明されたため、各社の提案内容がかなり異なるものと } \\
\text { なり、選定できなくなった。結果、条件を揃えての再提案を求められた。 }\end{array}$ \\
\hline & 21 & $\begin{array}{l}\text { 要項書類は簡易なもので、実際の設計要求は施主との個別面談による質疑 } \\
\text { によって伝えられため、募者間の持つ情報に不平等が生じた。 } \\
\end{array}$ \\
\hline & 22 & $\begin{array}{l}\text { 募集時に示される資料が多すぎたために、文書間に矛盾点が多く、質疑時の } \\
\text { 調整等に困難があった。 }\end{array}$ \\
\hline & 23 & $\begin{array}{l}\text { 募集要項にて示される課題の重み付けが不明瞭であったが、結局課題の } 1 \text { } \\
\text { を軽視した提案が当選した。 }\end{array}$ \\
\hline & 24 & $\begin{array}{l}\text { 質疑に対する回答が提出の直前に行われ、スケジュールに大きな影響を及 } \\
\text { ぼした。 }\end{array}$ \\
\hline & 25 & 提案の要求内容に比べ、提出までの期間が 2 週間と短かった。 \\
\hline & 26 & $\begin{array}{l}\text { 提案枚数に制限がなく、提案後にも追加資料を求められ、膨大な作業量と } \\
\text { なった }\end{array}$ \\
\hline & 27 & $\begin{array}{l}\text { 提案書提出のあと、再度コスト面での競争を強いられた。審査基準に対する } \\
\text { 困惑と二労力が発生した。 }\end{array}$ \\
\hline & 28 & 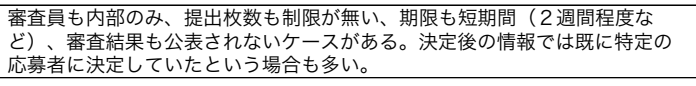 \\
\hline & 29 & $\begin{array}{l}\text { 内部者のみによる選定で透明性がなく、始めから特定の業者と組む予定であ } \\
\text { りながらアイデアの吸収するあの提案競技であった、という疑念が残っ } \\
\text { た。 }\end{array}$ \\
\hline & 30 & $\begin{array}{l}\text { 提案書の提出後にPMの存在が判明。過去に他社との財務関係があったこと } \\
\text { が判明し、何らかの疑念が残る結果となった }\end{array}$ \\
\hline & & \\
\hline & 31 & $\begin{array}{l}\text { 設計がほぼ終了している段階で事業が頓挫したが、設計料が支払われな } \\
\text { かった。 }\end{array}$ \\
\hline & 32 & 特定後、施主との打ち合わせがほとんどないまま、数ヶ月で破談した。 \\
\hline & 33 & $\begin{array}{l}\text { 特定後、委託金額内で敷地内の別棟の実施設計も対応するよう依頼され、や } \\
\text { むなく応諾せざる得なかった }\end{array}$ \\
\hline & 34 & $\begin{array}{l}\text { 選定基準があいまいだった、条件が一定ではなかった、気に入る提案がな } \\
\text { かった等の理由(憶測)てで提案の特定に至らず、指名者を入れ替えて再びプ } \\
\text { ロポーザルが行われた。指名型のプロポーザルを実施した際の発注者の義務に } \\
\text { ついての規定がない。 }\end{array}$ \\
\hline & 35 & 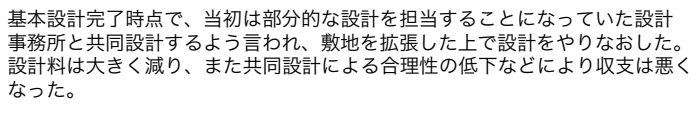 \\
\hline
\end{tabular}

十分な段階で選定が実施されたケースなどである。このため、応募 時に設計者が示した提案を設計時に大きく変更しなければならなか ったり、事業そのものが頓挫する場合もあった。プロポーザル方式 の場合は、「案」ではなく「人」を選ぶ選定であるため、特定後の提 案の変更は起こりえるとしても、計画提案を求める以上、ある水準 での準備ができている必要がある。

また、敷地や規模などの基本的な与条件が示されなかったために、 各応募者がそれを想定して提案しなければならないケースもあった。 結果、一定の基準での審査が不可能となり、条件を統一した上で再 度提案を求めることになった。この場合は、発注者と応募者の双方 にとって無駄な時間と労力を要する非効率な選定であり、避けるべ きである。

(2)は、設計事務所と建設会社設計部の双方を指名して選定が行わ れたケースである。設計完了後に建設会社に対し競争入札を行う設 計事務所と、施工まで一貫して請け負う建設会社とでは示寸提案の 意味合いが異なり、特に工事費の提案を合わせて求める場合は、並 べて審査することは不可能である。設計と施工とを分離して発注す る前提で建設会社の設計部に提案を求める場合は、設計・施工を合 わせて請け負うことで発揮される技術面やコスト面でのメリットが 期待できない。また、設計会社と建設会社の J V に対して提案を求 める場合は、要項でその業務分担や責任の所在を明記し、それを最 後まで遵守しなければその利点が活かせない。

(3)は、公平性や透明性に疑いを抱かれる選定や、無理なスケジュ ール設定など、選定の進め方に問題のあったケースである。何かし らの提案による競技形式をとる場合、公平性や透明性が求められる ことは当然であり、また案の盗用や流用など、知的生産行為に対す る認識や各方式の適切な運営方法についての理解を発注者に求める 必要がある。

(4)は、事業が頓挫した場合や追加業務に対する設計料の支払いや、 選定で特定を受けた者の権利、プロポーザルを実施した側の義務な どに関する問題など、主に契約に関して問題とされたケースである。

\section{3. マニュアルの作成}

\section{( 1 ） マニュアルの目的}

本マニュアルでは、上述したそれぞれの問題要因に対し発注者に 次のような指針を示すことで、これを回避することを目指した。

(1) : 諸条件が確定していない状況で具体的な提案を求めるような選 定が実施されることを避けるため、発注者に対しプロジェクト進 行状況の認識を促し、これに対応した設計者選定方式を提示する。

(2)：設計事務所と建設会社の特徵を示した上で、以後の業務につい て選択可能な発注先の組み合わせを提示し、それぞれに対応した 設計者選定方式を提示する。

(3), (4) : 各選定方式の特徴を示した上で、具体的な内容や進め方、 発注者の義務と特定者の権利などの注意事項を提示する。

\section{(2) マニュアルの構成}

本マニュアルは、web ページ上で展開することを想定し、閲覧者（発 注者）が示された選択肢を選択していくことで適切な選定方式とそ の具体的な内容を閲覧できるよう構成した。マニュアルの全体構成 を図に示す（図 1)。 
○第 1 段階

医療施設の企画から施工に至るまでの一連のプロジェクトフロー を示し、その中で発注者自身の進行状況を確認し、「事業段階」を選 択してもらう。

○第 2 段階

選択された各事業段階ごとに、以後のどの段階をどのような相手 に委託できるか、その組み合わせを示す。また、それぞれの組み合 わせにおいて発生する「設計者選定場面」を示し、選択してもらう。

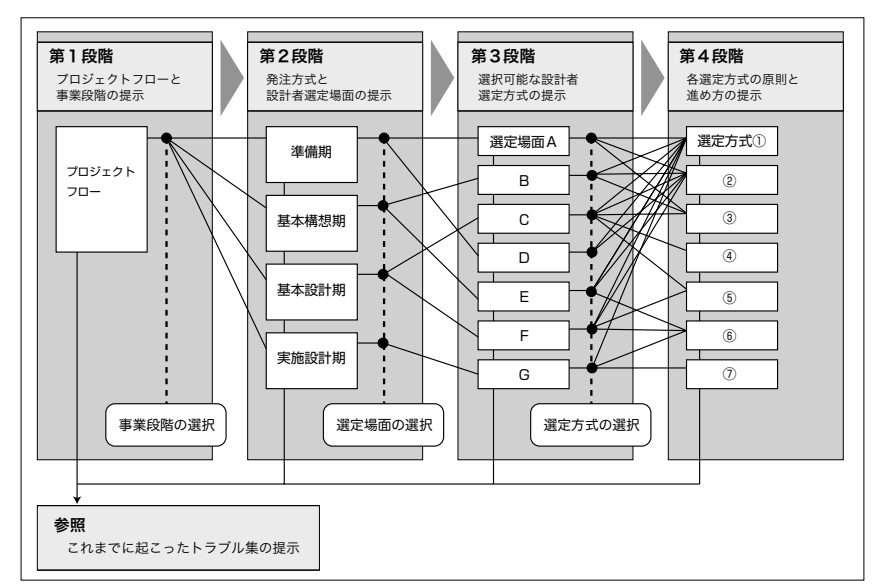

図 1 マニュアルの基本構成

表2 第 1 段階：プロジェクトフローと事業段階

\section{○第 3 段階}

選択された「設計者選定場面」ごとに、採用可能な「設計者選定方式」 の一覧とその概要や特徵を示し、選択してもらう。

○第 4 段階

選択された「設計者選定方式」の具体的な内容や進め方を示す。 ○参照

各段階より、誤った選択や状況が未確定なままで選定を進めた場 合に起こりえるトラブル集として調查で収集したエピソードを示し たページにリンクを貼る。

\section{（3）マニュアルの内容}

\section{○第 1 段階：事業段階の認識}

参考文献 5）を元に、医療施設の企画から施工に至る一連のプロジ エクトフローを作成した (表 2 )。このフローから未達成の項目を把 握することで、自身の事業が現在どの段階にあるかを認識できる。 例えば、「7 : 決意」として事業の実施が確定していない場合、事業 が「準備期」の途中であり、また「1 3 : 敷地の確定」が成されて いない場合は事業が「基本構想期」の途中であることになる。

このように、発注者自身の事業の進行度を認識してもらうことで、 与条件が不十分な段階での設計提案を求める選定などを回避する。

○第2段階：設計者選定場面の選択

第 1 段階で選択された事業段階ごとに、以後の業務の委託先の組

プロジェクト

フローと事業段階

説明文

準備期：総意として事業の実施を決定する時期であり，事業の概略について，必要性とその実行可能性を協議・検討する。

\begin{tabular}{l|l|l}
1 & ○事業実施必要性の確認 & 予定する事業の実施の必要性と妥当性, スケジュールについて, 最低限, 幹部の総意を得る \\
\hline
\end{tabular}

\begin{tabular}{l|l} 
医療需要調査 & 地域の医療需要分析から, 事業の必要性や妥当性を検討する \\
\hline 医療施設調査 & 現施設の経営状況, 既存施設の継続利用可能範囲などの分析から, 事業の必要性や妥当性を検討する \\
\hline 経営資料の収集・分析 & 現施設の経営状況分析から, 事業の実行可能性を検討する \\
\hline 財源確保の見通し & 事業を実施するための財源確保の見通しを関係機関と協議する \\
\hline 敷地確保の見通し & 事業を実施するに相応しい敷地（あるいは現有敷地の妥当性）を検討する \\
\hline 決意 & 事業実施に関する必要性・妥当性・実行可能性を検証した上で, 幹部あるいは施設職員等関係者の総意を得る
\end{tabular}

基本 構想 (計画) 期 : 準備期に想定した概略の事業計画について，様々な側面間に矛盾のない，妥当性のある基本設計条件を決定する。その際，試案として基本計画図を作成する場合もある。

8 ○基本構想 (計画) の立案 $\quad$ 建設予定施設の，管理・運営・建築について，大筋（基本構想）を定める

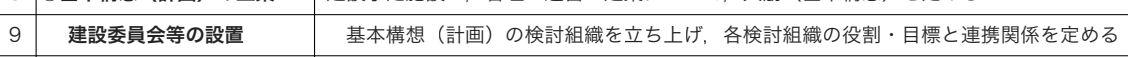

10 地域の現状分析 $\quad$ 地域の医療需要について, 詳細情報を収集し, 必要な医療機能を把握する

11 病院機能および規模の確定 $\quad$ 必要とされる医療機能に対する人員・利用予測結果等々を勘案し、計画施設の機能・規模，あるいは既存施設の利用方法を設定する

12 管理運営基本方針の決定 $\quad$ 想定された医療機能に対応する管理・運営方針を定める

13 敷地の確定 $\quad$ 気候・地盤・周辺・交通等々の状況，建築関係諸法令を確認の上、敷地を決定する

14 建築・設備の基本構想 $\quad$ 上記を踏まえた基本設計条件を整理する（試案として基本計画図を作成する場合もある）

15 建設費の概算 $\quad$ 基本設計条件に基づく建設費の概算を行う（基本計画図に基づく場合もある）

経営規模と方針 $\quad$ 人員確保・建設費などに基づく, 経営規模の妥当性を確認する

基本 設計期 : 基本構想（計画）期の基本設計条件に基づき, 具体的実施案（財源確保・管理運営方式・基本設計図など）を作成する。

\begin{tabular}{|c|c|c|}
\hline 17 & 財源確保の方針確定 & 経営規模に応じた財源確保策について確定する \\
\hline 18 & ○敷地の詳細調査 & 敷地の測量・地質調査・土壤污染調査等を行う（基本構想（計画）期には実施されていることが望ましい） \\
\hline 19 & 基本設計 & 更に詳細な施設利用者の要望を把握し，施設の各部門·各室の間取り，機能・性能等を設定し，基本設計図書をまとめる \\
\hline 20 & 各種関連法規の事前協議 & 医療関係・建築および消防関係等々，関連する法規について，関係する諸機関と事前協議を進める \\
\hline 21 & ○建設費の試算 & 基本設計図書を基に，建設費の概算を行う \\
\hline
\end{tabular}

実施設計 \& 監 理期：基本設計期の実施案を，建設工事に向けた実施設計図として作成する。またその実施設計図に基づく施工過程を監理する。医療機器や家具等の購入計画との調整を図る。

\begin{tabular}{|l|l|l|}
22 & 実施設計 & 施設利用者の要望に基づき，各部門・各室の詳細性能・機能を確定し，工事業者に向けた実施設計図書としてまとめる \\
\hline 23 & 確認申請等の各種手続き & 建築確認申請を始め, 関係諸機関への届け出書類を作成する \\
\hline 24 & 監理 & 建設費の確定，医療機器・備品費の確定，総事業費の確定 \\
\hline 25 & 総事業費の確定 & 実施設計図書に基づく設計監理，変更や未決定部分等への対応，調整等を行い，建築的完成度を上げる \\
\hline
\end{tabular}




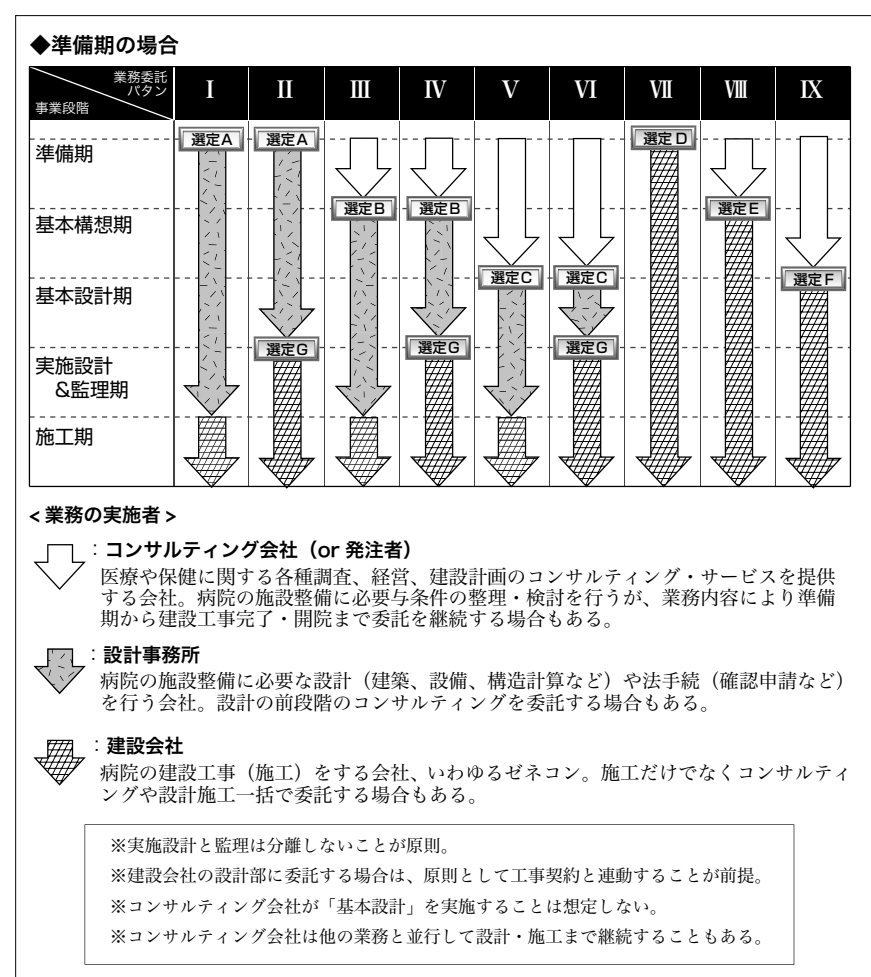

図2 第 2 段階：業務委託パタンと設計者選定場面

み合わせ（業務委託パタン）を示す（図２）。例えば、業務委託パタ ン I は、準備期から実施設計期までを設計事務所に委託する形であ る。また、パタン $\mathrm{V}$ は、基本構想期までをコンサルティング会社に 委託するか、もしくは発注者自身が実施し、基本設計期から設計事 務所に委託する形であり、これは一般的な公共発注の形といえる。 また、パタンVIIIは、準備期までをコンサルティング会社に委託するか、 もしくは発注者自身が実施し、基本構想期から施工まで建設会社に 委託する形である。なお、事業段階が基本構想期、基本設計期と進 むほど、業務発注パタンの選択肢は減少する。

各パタンにおいて、業務実施者の切り替わるタイミングが設計者 を選定する場面となり、それぞれで適用できる選定方式が異なる（表 3)。選定方式(3) 、公共発注を前提としたものであるため、建設会 社に設計を含む業務を委託する場合には適用できない。また、(4)、 (5)具体的な設計提案を必要とするため、設計与条件が確定してい ない段階では適用できない。このように、業務委託パタンと設計者 選定場面を整理し、発注者に選択してもらうことで、設計事務所と 建設会社が混同した設計者選定の実施などを回避する。なお、表 3 で示している選定方式は、参考文献 6) にて紹介されているものと、 社団法人医療福祉建築協会のガイドライン ${ }^{3}$ ) に準拠した方式 (JIHa 型プロポーザル方式とする）とを暫定的に採りあげた。

例えば、基本構想期が完了していない段階で設計事務所を対象と した選定を行う場合は業務委託パタンIII、IVでの選定 B となり、こ れには応募者に具体的な図面表現による提案を求める選定方法(4)や (5)適用できない。また、事業の実施が確定していない準備期にあ る段階で、建設会社を対象とした選定を行う場合は業務委託パタン VIIでの選定 Dとなり、これには具体的な設計計画案やそれに基づく 工事費の提案を求める総合評価方式は採用すべきでない。また、作 るものが決まっていないため、入札を行うことも避けるべきである。

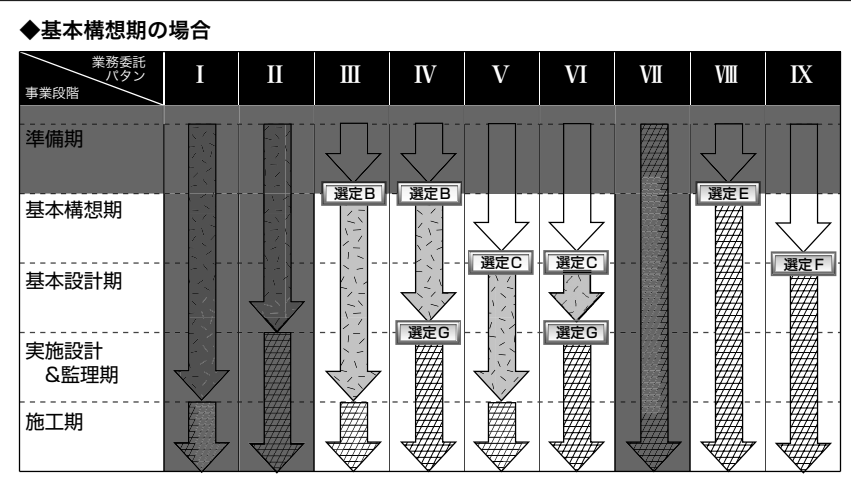

\section{基本計画期の場合}

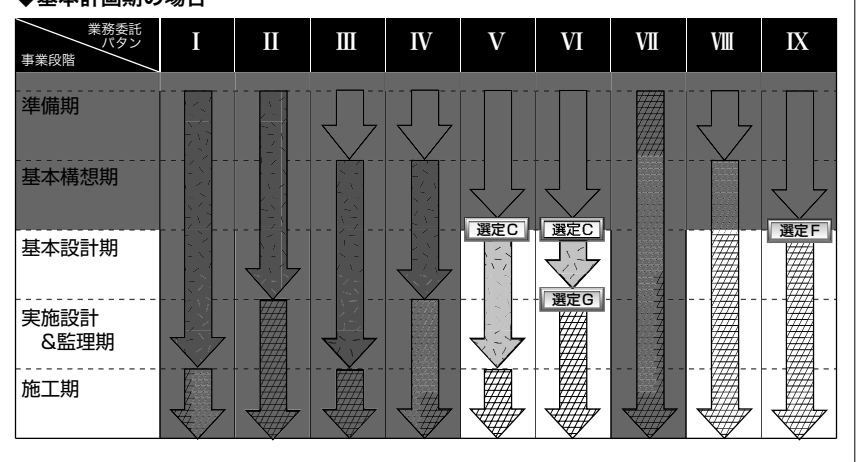

表3 設計者選定場面と設計者選定方式の対応

\begin{tabular}{|c|c|c|c|c|c|c|c|}
\hline 選定方式 選定ハタン & 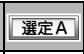 & 選定B & 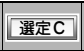 & 選定D & 選定 $\mathrm{E}$ & 選定F & 選定G \\
\hline (1)特命方式 & 0 & 0 & $\bigcirc$ & $\bigcirc$ & 0 & $\bigcirc$ & $\bigcirc$ \\
\hline (2)資質評価に基づく選定方式 & 0 & 0 & 0 & 0 & 0 & 0 & $x$ \\
\hline (3)国交省型プロポーザル方式 & 0 & 0 & O & $x$ & $x$ & $x$ & $x$ \\
\hline (4)JHa型プロポーザル方式 & $x$ & $x$ & 0 & $x$ & $x$ & $x$ & $x$ \\
\hline (5)設計競技方式 & $x$ & $x$ & 0 & $x$ & $x$ & 0 & $x$ \\
\hline (6)総合評価方式 & $x$ & $x$ & $x$ & $x$ & 0 & 0 & $\bigcirc$ \\
\hline (7)入札方式 & $x$ & $x$ & $x$ & $x$ & $x$ & $x$ & $\bigcirc$ \\
\hline
\end{tabular}

表4 第 3 段階: 選択可能な設計者選定方式の一覧

\begin{tabular}{|c|c|c|c|c|c|c|c|}
\hline \multirow[b]{2}{*}{ 方式名称 } & \multirow{2}{*}{$\begin{array}{c}\text { 概要 } \\
\text { (一部参考文献 } 6 \text { より引用) }\end{array}$} & \multirow{2}{*}{$\begin{array}{l}\text { 評価 } \\
\text { 対象 }\end{array}$} & \multicolumn{2}{|l|}{ 提案 } & \multirow{2}{*}{ | } & \multicolumn{2}{|c|}{ 負担労力 } \\
\hline & & & 内容 & \begin{tabular}{|l|} 
囿面の \\
無
\end{tabular} & & $\begin{array}{l}\text { 發注 } \\
\text { 者 }\end{array}$ & 虙募 \\
\hline (1) & $\begin{array}{l}\text { 發注者が、設計者の能力、実績 } \\
\text { 作評判等を調查し詯の } \\
\text { 見識と責任において設者を直 } \\
\text { 接指名る。 }\end{array}$ & - & - & - & 0 & - & - \\
\hline $\begin{array}{l}\text { 2) } \\
\text { 資質評価 } \\
\text { に基づく } \\
\text { 選定方式 }\end{array}$ & 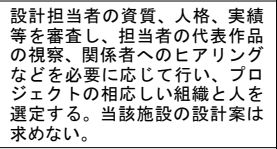 & 実績等 & - & - & 0 & 中 & 小 \\
\hline $\begin{array}{l}\text { 3) } \\
\text { 国交省型 } \\
\text { プロポー } \\
\text { ザル方式 }\end{array}$ & 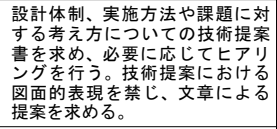 & $\begin{array}{l}\text { 実績+ } \\
\text { 文章提案 }\end{array}$ & \begin{tabular}{|l|}
$\mid$ 実績, 寅施体 \\
制, 課題に対 \\
するる考え方
\end{tabular} & $\Delta$ & 0 & 中 & 中 \\
\hline $\begin{array}{l}\text { (4) } \\
\text { JlHa型 } \\
\text { プロポー } \\
\text { ザル方式 }\end{array}$ & 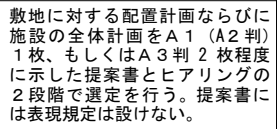 & 設計案 & \begin{tabular}{|l|} 
総合的な設計 \\
提案, 実施体 \\
制（実績は参 \\
考程度）
\end{tabular} & 0 & 0 & 中 & 中 \\
\hline $\begin{array}{l}\text { (5) } \\
\text { 設計競技 } \\
\text { 方式 }\end{array}$ & 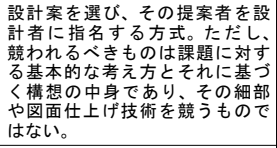 & |設計提案 & $\begin{array}{l}\text { 配置, 平面, } \\
\text { 立面、等 } \\
\text { 設計図面 }\end{array}$ & 0 & $\Delta$ & 大 & 大 \\
\hline $\begin{array}{l}\text { 6) } \\
\text { 総合評価 } \\
\text { 方式 }\end{array}$ & 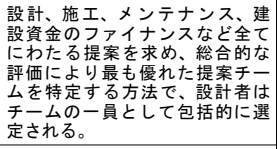 & 総合提案 & $\begin{array}{l}\text { 事業提案書 } \\
\text { (設計図, } \\
\text { 事業等) }\end{array}$ & 0 & $\Delta$ & 中 & $\begin{array}{l}\text { 中 } \\
\text { 大 }\end{array}$ \\
\hline $\begin{array}{l}(7) \\
\text { 入札方式 }\end{array}$ & 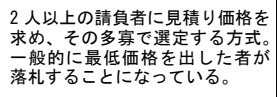 & 金額 & $\begin{array}{l}\text { 設計料や } \\
\text { 工事費 }\end{array}$ & - & 0 & 小 & 小 \\
\hline
\end{tabular}




\section{○第3段階：設計者選定方式の選択}

第 2 段階で選択された設計者選定場面ごとに、選択可能な設計者 選定方式とその概要や比較表 ${ }^{1)}$ を示し、参照した上で選択してもら う。表 4 は全ての方式を示しているが、web 上では選択可能な選定方 式のみ表示されるようにする。

\section{○第4段階：各方式の理解}

第 3 段階で選択された設計者選定方式ごとに、その詳細説明や具 体的な進め方を示す（本報告では割愛する）。

\section{4. まとめ}

以上のように、発注者の準備不足や認識不足に起因寸る設計者選 定の問題点を回避するためのマニュアルの基本構成までを作成した。 各段階の詳細な内容についてはまだブラッシュアップの余地がある ものの、発注者に示すべき内容項目と、正しい選定方式へと導く道 筋は示せた。

また今後は、設計事務所と建設会社の J V 形式、P M 方式、CM 方式、P F I 方式など、他の発注方式についても対応していく必要 があろうが、今回はどのタイミングでどのような相手に対し選定を 行う場面がありえるかについて整理することを優先した。

また、参考文献 3 ） の「図面的表現の禁止は、医療・福祉施設に とって不都合な制約となっている」という主張を前提とした場合、 基本構想が固まっていない段階で図面提案を求めての選定を行う新 たな方式を検討する必要があり、今後の課題としたい。

\section{5. あとがき}

本研究は、社団法人日本医療福祉建築協会の情報委員会の事業と して行った。

また、現状調查において、お忙しい中たくさんの方々にご協力い ただいた。ここに記し深く感謝の意を表す。

\section{参考文献}

1）瀬口哲夫 他 : まちづくり教科書 第 4 巻 公共建築の設計者選定 日本建築学 会 編, 丸善, 2004.3,

2) プロポーザルマニュアル委員会編 : 設計プロポーザルの進め方 プロポーザ ル方式による設計者選定マニュアル，公共建築協会，p10-12, 1998.8

3）社団法人 日本医療福祉建築協会編, “医療・福祉施設の設計プロポーザル・ガ イドライン”, 社団法人 日本医療福祉建築協会, 2002-1, http://www.jiha. jp/press.html, (参照 2008-3)

4) 鈴木啓・中山茂樹 : 病院建築プロポーザルにおける課題の構成と提案の求め 方に関する調査 - 医療・福祉施設の設計者選定に関する研究 -, 日本建 築学会計画系論文集, No. 631, pp. 1883-1889, 2008.9

5）吉田幸雄 他: 病院管理大系 第 6 巻 I 建築・設備・医療機械 I, 医学書院, 1980. 11

6）社団法人建築業協会 $\cdot$ 社団法人日本建築家協会 $\cdot$ 社団法人建築学会 $\cdot$ 社団 法人日本建築士会連合会 $\cdot$ 社団法人日本建築士事務所協会連合会 : 公共建 築の設計者選定方法の改善についての提言，2003.9, http://www.aij.or.jp/ scripts/request/document/030930.pdf，（参照 2008-10）

[2008 年 10 月 20 日原稿受理 2009 年 1 月 16 日採用決定 $]$ 